\title{
Benefit Measurement Method Aimed at Application of Consumer Surplus Approach*
}

毛利雄一**・桐越 信***・安部勝也****

By Yuichi MOHRI** - Shin KIRIKOSHI*** - Katsuya ABE****

\section{1.はじめに}

現在、各種公共事業の実施にあたっては、その効率 性及び実施過程の透明性の向上を図るため、費用便益 分析を含めた評価が実施されている。道路事業におい ても、…定の要件に該当する事業については、それぞ れ必要とされる時期の評価のひとつの要素として費用 便益分析の実施が義務づけられており、費用便益分析 の実施は制度化されつつある状況にある。

道路事業を対象とした新規採択の評価及び再評価にお ける費用便益分析については、将来の当該道路の整備 あり、整備なしの交通量及び一般化費用から便益が算 定されるため、交通需要予測手法が密接に関係してい る。そのため、実務で道路事業の費用便益分析を実施 していくうえでは、経済理論と整合の図られた交通需 要予測方法を理解し、本来どのような方法で交通需要 予測を行って便益を計測する必要があるか、また実務 で適用可能な交通需要予測方法を理解し、どのような 前提条件で便益を計測するのかを整理しておく必要が ある。本論文では、経済理論に基づいて、より正確に 便益を計測するための交通需要予測方法を整理すると ともに、実務への適用において、どのような対応がで きるのかを検討する。

*キーワーズ : 消費者余㮃アプローチ、便益計測、 交通量配分

**正員、工博、（財）計量計画研究所

（東京都新宿区市ヶ谷本村町2-9、 TEL03-3268-9911、FAX03-5229-8102)

***正員、工博、東京都建設局

（東京都新宿区西新宿2-8-1、 TEL03-5320-5311、FAX03-5388-1531)

****正員、工修、内閣府

（東京都千代田区霞が関3-1-1、 TEL03-3581-0764、FAX03-3581-0887)

\section{2. 便益計測と交通需要予測方法の関係}

（1）消費者余剰アプローチによる社会的余剩1)

経済理論（この場合、ミクロ経済学）において、便 益の計測は消費者余剩と生産者余剩の和としての社会 的余剩の計測によって行われる（消費者余㮃アプロー チと呼ぶ）。図一 1 において、 $\mathrm{D}=\mathrm{D}(\mathrm{P})$ は需要関数、 $\mathrm{P}(\mathrm{Q})$ は利用者が負担する様々な費用をすべて含む一般 化費用関数、 $\mathrm{C}(\mathrm{Q})$ は社会的限界費用関数である。なお、 図-1 では価格体系に歪みがあり、一般化費用関数 $\mathrm{P}(\mathrm{Q})$ と社会的限界費用関数 $\mathrm{C}(\mathrm{Q})$ が 一致せず、均衡点 において、価格 $\left(\mathrm{P}^{*}\right)$ と社会的限界費用 $\left(\mathrm{C}^{*}\right)$ が 致しない状況を想定している。

$\mathrm{P}(\mathrm{Q})$ と $\mathrm{D}(\mathrm{P})$ の交点 $\mathrm{B}$ で, 価格 $\mathrm{P}$ と需要量（供給 量） $\mathrm{Q}$ がそれぞれ $\mathrm{P}^{*} 、 \mathrm{Q}^{*}$ に決まるとすると、下記が 得られる。

$$
\begin{aligned}
& \mathrm{CS} \text { （消費者余剰） }=\mathrm{ABP}^{*} \text { (1) } \\
& \mathrm{PS} \text { (生産者余剩) }=\mathrm{P}^{*} \mathrm{BEF} \text { (2)+(3)+(4)) } \\
& \mathrm{PQ} \text { (収入) }=\mathrm{P}^{*} \mathrm{BQ}{ }^{*} \mathrm{O}(\text { (2) + (3)+ (4) + (5)) } \\
& \text { GCS（グロスの消費者余剰） } \\
& =\mathrm{ABQ} * \mathrm{O}(\text { (1) + (2) + (3) + (4) + (5) }
\end{aligned}
$$

$\mathrm{SC}$ (社会的費用) $=\mathrm{EFQ}^{*} \mathrm{O}$ (5)

社会的余㮃(B)は、消費者余剩(CS) と生産者余剩(PS)の 和であるので、

$$
\mathrm{B}=\mathrm{CS}+\mathrm{PS}=\mathrm{ABFE} \text { (1)+(2)+(3)+(4) }
$$

となる。---方(4)式より、グロスの消費者余剰(GCS)は、

$$
\mathrm{GCS}=\mathrm{CS}+\mathrm{PS}+\mathrm{SC}=\mathrm{B}+\mathrm{SC}
$$

となり、社会的余剩(B)は、以下の $(8)$ 式で示される。

$$
\mathrm{B}=\mathrm{GCS}-\mathrm{SC}
$$

以上から、プロジェクト実施による整備効果の把握 は、プロジェクトを実施した場合（状態 W）と実施 しない場合（状態 $\mathrm{O} ）$ の社会的余剩（B）の差（ $\triangle \mathrm{B}$ $\left.=\mathrm{B}^{\mathrm{W}}-\mathrm{B}^{\mathrm{O}}\right)$ として把握されることになり、社会的余 剩の差（ $\triangle \mathrm{B} ）$ は式（9）より計測される。 


$$
\begin{aligned}
\triangle \mathrm{B}=\mathrm{B}^{\mathrm{W}}-\mathrm{B}^{\circ}=\left(\mathrm{GCS}^{\mathrm{W}}-\mathrm{SC}^{\mathrm{WV}}\right)-\left(\mathrm{GCS}^{\circ}-\mathrm{SC}^{\mathrm{O}}\right) \\
=\left(\mathrm{GCS}^{\mathrm{W}}-\mathrm{GCS}^{\circ}\right)-\left(\mathrm{SC}^{\mathrm{W}}-\mathrm{SC}^{\circ}\right) \\
=\triangle \mathrm{GCS}-\triangle \mathrm{SC}
\end{aligned}
$$

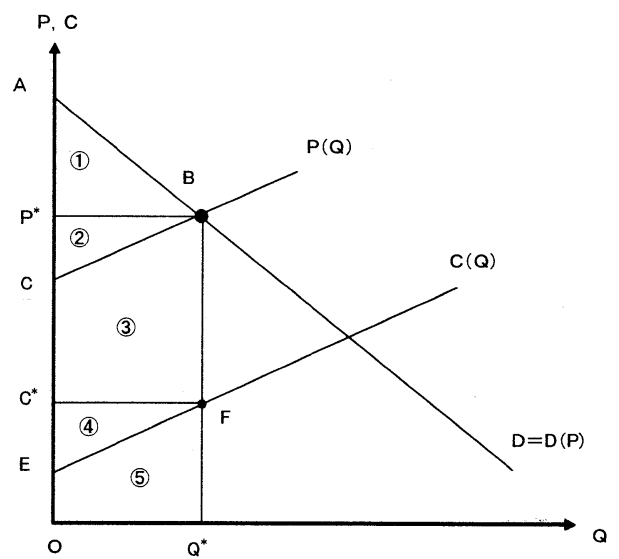

図－1社会的余剩=消費者余剩＋生産者余利

（価格体系に歪みがある $P(Q) \neq C(Q)$ の場合）

（2）便益計測方法と交通需要予測方法の関係

消費者余剩アプローチから示される式(9)の社会的 余剩の差 $(\triangle B)$ のうち、社会的費用の減少分 $(\triangle S$ C）については、交通量配分モデルに基づいて、道路 整備あり・なしのそれぞれから得られる交通量及び 般化費用によって算出される。しかし、グロスの消費 者余剩の増加分 $(\triangle \mathrm{GCS})$ を正確に計測できるかどうか は、交通需要予測の方法と密接に関係してくる ${ }^{1) 22}$ 。 この関係について、表ー 1 に整理する。表 -1 の結果 から、消費者余剩アプローチによる上記 (9) 式で表さ れる便益計測からみると、 $\triangle \mathrm{GCS} \neq 0$ となる交通需要 予測方法は、需要変動型のOD交通量の予測方法であ ること、また競合路線に完全代替を仮定しない配分交 通量の予測方法である。逆に、グロスの消費者余剩の 增加分 $(\triangle \mathrm{GCS})=0$ となる交通需要予測方法は、OD交

\section{表－1 $\triangle \mathrm{GCS}$ と交通需要予測の関係}

\begin{tabular}{|c||c|c|}
\hline $\begin{array}{c}\text { 配分交通量 } \\
\text { (経路交通量) }\end{array}$ & $\begin{array}{c}\text { Wardrop 第 1 原則 } \\
\text { の実現を仮定 } \\
\text { (完全代替を仮定) }\end{array}$ & $\begin{array}{c}\text { Wardrop 第 1 原則 } \\
\text { の実現を仮定せず } \\
\text { (完全代替を仮定せず) }\end{array}$ \\
\hline \hline D交通量
\end{tabular}

通量が需要固定型の予測方法であり、かつ配分交通量 の予測方法が競合路線に完全代替を仮定するWardrop の第 1 原則（「等時間原則」）に従う場合である。

（3）便益計測のための交通量配分モデルからのアウ トプット

消費者余剰アプローチによる便益は、消費者である 道路利用者の経路選択という意思決定に基づく経路交 通量とその一般化費用によって算定される。交通量配 分モデルは、自動車OD交通量と道路ネットワーク及 びリンク抵抗を示すリンクパフォーマンス関数をイン プットとし、リンク交通量、リンク旅行速度、OD間 所要時間、経路交通量等をアウトプットする。便益を 計測する際には、交通量配分モデルからアウトプット される経路交通量もしくはリンク交通量とそれに対応 する一般化費用を用いる。

需要固定型予測において、既存道路の拡幅等による 道路の改良の場合は、道路改良あり（with）・なし

（without）の経路交通量もしくはリンク交通量（ $\mathrm{Q}_{1}{ }^{\mathrm{O}}$, $\left.\mathrm{Q}_{1}{ }^{\mathrm{W}}, \mathrm{Q}_{2}{ }^{\mathrm{O}}, \mathrm{Q}_{2}{ }^{\mathrm{W}}\right)$ とそれに対応する一般化費用（ $\mathrm{P}_{1}{ }^{\mathrm{O}}$, $\left.\mathrm{P}_{1}{ }^{\mathrm{W}}, \mathrm{P}_{2}{ }^{\mathrm{O}}, \mathrm{P}_{2}{ }^{\mathrm{W}}\right)$ が交通量配分より算出され、便益計測 が可能である。しかし、図ー 2 に示すように路線 1 の
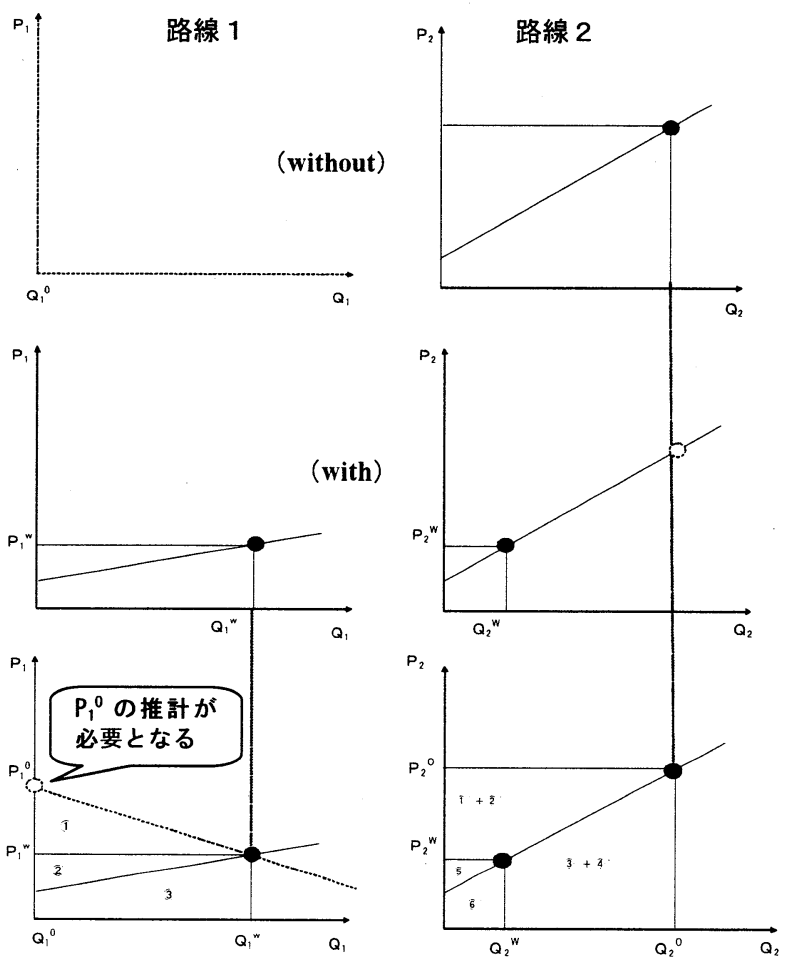

図一2 道路新設（路線 1 ）における便益計測 
道路が新設され、新規経路もしくはリンクが追加され る場合、の便益計測では、道路整備なし（without）の 一般化費用 $\left(\mathrm{P}_{1}{ }^{\mathrm{O}}\right)$ の推計が必要となる。具体的には、 道路整備なし（without）の状態において、仮想的に新 設道路を設定し、その利用交通量が 0 となる場合の． 般化費用（禁止価格）の推計が必要となる。

\section{3. 交通量配分モデルからみた便益計測方法}

将来交通需要予測における 1 日を対象とした静的 な交通量配分モデルは、確定的利用者均衡配分

（UE：User Equilibrium）と確率的利用者均衡配分
(SUE : Stochastic User Equilibrium) に大別される。 以下に、それぞれの特徴と便益計測方法を示す。

（1）確定的利用者均衡配分（UE）

確定的利用者均衡配分によって各経路に配分される 交通量では、Wardropの第 1 原則である「等時間原 則」が仮定され、経路選択肢間に完全代替性が成立す ることが前提となっている。

図ー3の左に示すように、般化費用は時間と料金 の線形和で算出され、各経路間の一般化費用は等しい。 また、経路 3 の道路が新設された場合の経路ベースで の便益計測法では、道路整備あり（with）・なし

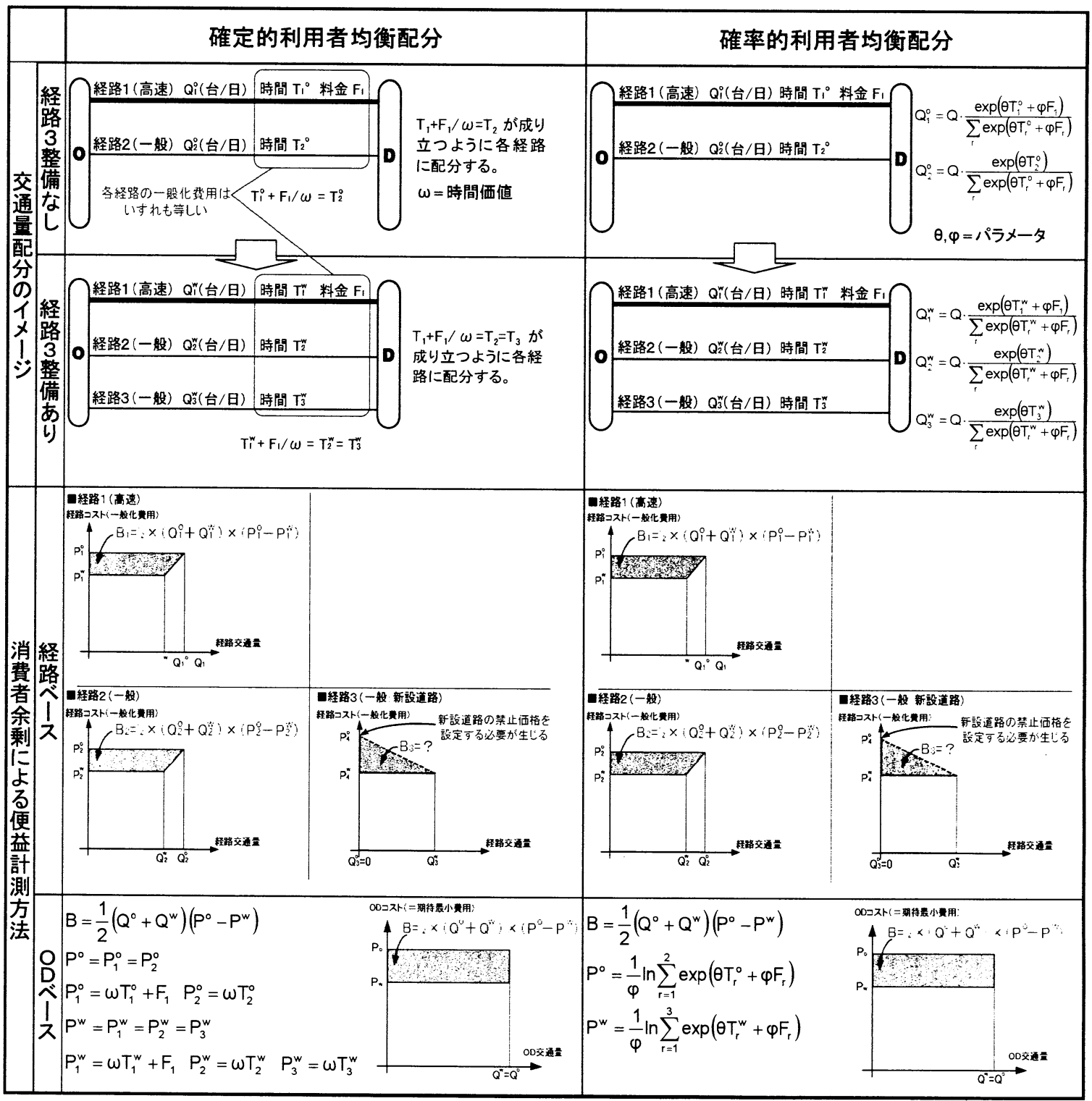

図-3 確定的・確率的利用者均衡配分における便益計測の考え方（OD交通需要固定の場合） 
(without)において、それぞれの経路の一般化費用が 等しくなるように交通量が算定され、各経路の消費者 余剩の変化を合算することにより、便益が算定される。 但し、2.(3)で示したように、新設される経路 3 につい ては、道路整備なし（without）の一般化費用（敕止価 格）の推計が必要がとなる。さらに、確定的利用者均 衡配分では、リンク交通量は・意に決まるが、経路交 通量については一意に定まる保証はない。

一方、ここでの OD ベースでの便益計測方法では、 ある OD 間の各経路の一般化費用は等しいことから、 $\mathrm{OD}$ 間の-・般化費用は・意に定まり、道路整備あり (with) ・なし (without) の $\mathrm{OD}$ 交通需要 $\left(\mathrm{Q}^{\mathrm{O}}, \mathrm{Q}^{\mathrm{W}}\right)$ とそれに対応する $\mathrm{OD}$ 間の一般化費用 $\left(\mathrm{P}^{\mathrm{O}}, \mathrm{P}^{\mathrm{W}}\right)$ から なる台形の面積（ここでは OD 交通需要固定であるた め、 $\mathrm{Q}^{\mathrm{O}}=\mathrm{Q}^{\mathrm{W}}$ となり長方形の面積）を算定すれば良い。 この方法によって、上記の新設道路における道路整備 がない場合の一般化費用設定の問題が解決される。

確定的利用者均衡配分は、現況再現性向上のための リンクパフォーマンス関数の設定等、いくつか課題が 存在するが、十分に実務で適用可能な段階にある3)。

\section{（2）確率的利用者均衡配分（SUE）}

確率的利用者均衡配分は、ランダム効用理論に基づ く離散選択モデルに従って経路選択を行うと仮定し、 所要時間や料金といった経路每のサービス特性に加え、 意思決定者の個人属性、トリップ目的などのトリップ 特性が各利用経路の効用に影響を及ぼし、個人はこの 利用可能な経路の中から最大の効用を与える経路を選 択する。従って、前述の確定的利用者均衡配分と違い、 経路選択肢間における完全代替性を仮定していない。 そのため、図ー 3 の右に示すように、各経路の効用は、 旅行時間、料金等の関数から設定され、各経路の効用 值は等しくなるとは限らない。

また、経路 3 の道路が新設された場合の経路ベース での便益計測方法では、道路整備あり（with）・なし

（without）におけるそれぞれの経路の効用值から算出 される一般化費用とそれに基づく経路選択確率から交 通量が算定され、各経路の消費者余剩の変化を合算す ることにより、便益が算定される。但し、確定的利用 者均衡配分と同椂に、新設される経路 3 については、 道路整備なし（without）の・般化費用の推計が必要と なる。
一力、OD ベースでの便益計測方法では、OD 間の 利用可能な経路の選択肢集合が設定されれば、OD 間 の最小認知費用の期待值（期待最小費用と呼ぶ）が． 意に定まり、道路整備あり（with）・なし（without） の $\mathrm{OD}$ 交通需要 $\left(\mathrm{Q}^{\mathrm{O}}, \mathrm{Q}^{\mathrm{W}}\right)$ とそれに対応する $\mathrm{OD}$ 間 の期待最小費用 $\left(\mathrm{P}^{\mathrm{O}}, \mathrm{P}^{\mathrm{W}}\right)$ からなる台形の面積（ここ では $\mathrm{OD}$ 交通需要固定であるため、 $\mathrm{Q}^{\mathrm{O}}=\mathrm{Q}^{\mathrm{W}}$ となり長 オ形の面積）を算定すれば良い。

2.(2)で示した消費者余剩アプローチによるより正 確な便益計測から要求される交通需要予測方法は、競 合路線の完全代替を仮定しない配分の予測方法である。 この前提条件を満たす配分方法としては、確率的利用 者均衡配分の適用が望ましい。また、確率的利用者均 衡配分は、便益計測から要求されるもう 1 つの前提条 件である需要変動型予測への展開についても、ランダ ム効用理論に基づく離散選択モデルであるため、上位 の分担や分布モデルとの適切な整合が図れる方法であ る。

しかし、実際に実務で適用していくためには、以下 のような課題を抱えている。

(1)経路選択肢集合の設定方法が難しい

(2)均衡解を得るための実用的なアルゴリズムが必ず しも適切に確立されていない ${ }^{4)}$

(3)経路選択モデルのパラメータ推定のためのデータ が未整備である

\section{4. 実務におけるより正確な便益計測への対応}

ここでは、先に示した「2, 便益計測が要求する交 通需要予測方法」と「3. 交通量配分モデルからみた 便益計測方法」に基づいて、便益計測が要求する交通 量配分モデルの課題を再整理するとともに、実務への 適用にあたって、どのように対応していくことが可能 であるかを示す。

（1）便益計測からみた交通量配分モデルの課題

2.（2）で示した消費者余剩アプローチによる便 益計測の $\triangle \mathrm{GCS} \neq 0$ となる交通需要予測方法は、需要 変動型の予測方法であり、また競合路線の完全代替を 仮定しない配分交通量の予測方法である。先に述べた ように、この要求を満たすための配分手法としては、 確率的利用者均衡配分を適用することが望ましいが、 現段階で、確率的利用者均衡配分を実際に適用するた 
めには、先に示したように、いくつかの課題を抱えて いるため、実務で適用していくことは難しい。そのた め、消費者余剩アプローチによる便益計測が交通需要 予測方法に要求する内容に対し、実務で適用していく ための交通量配分モデルとして、どのような対応がで きるのかを明確にする必要がある。

実務で適用するためのもう 1 つ課題は、どのよう な単位で便益を計測するかである。先に示したように、

一般に、交通量配分モデルからアウトプットされる経 路交通量もしくはリンク交通量とそれに対応する -般 化費用を用いて便益計測が行われるが、この場合、新 設される経路の道路整備なし（without）の一般化費用

(禁止価格) の推計が必要がとなる。便益計測の誤差 を少なくし、より正確に推計するため、交通量配分モ デルからアウトプットされる計測単位についても明確

しておく必要がある。

次節では、上記の実務で適用するうえで課題となる 「1）便益の計測単位」、「2）競合路線の完全代替 を仮定しない交通量配分方法への対応」について示す。

\section{（2）実務における課題への対応}

1 ) 便益の計測単位について

消費者余㮃アプローチによって利用者便益を計測す るためには、道路利用者の需要曲線（一般均衡需要曲 線）を決定する必要があるが、一般に、この需要曲線 の推計は非常に困難である。このため、実際には、道 路整備なし（without）の‥般化費用・交通量と道路整 備あり（with）の一般化費用・交通量とを推計し、そ の間の交通需要は直線であると仮定することが多い。 その時の消費者余剩の変化は、図-4の台形部分の面 積に近似される。図ー4の $\mathrm{P}$ \%はwithoutケースの-・般

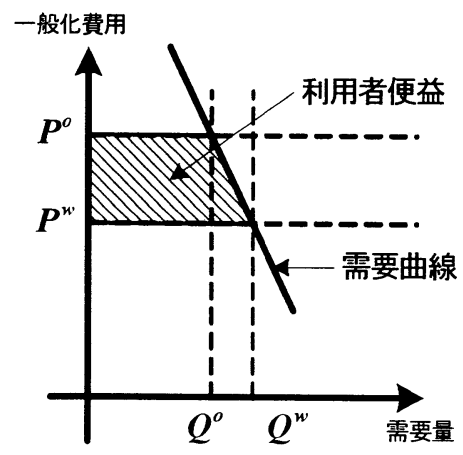

図-4 消費者余㮃の変化
化費用、 $\mathrm{P}^{\mathrm{w}}$ はwithケースの 般化費用、 $\mathrm{Q}^{\circ}$ はwithout ケースの需要量（交通量）、 $\mathrm{Q}^{\mathrm{w}}$ はwithケースの需要 量（交通量）である。

道路交通の需要量は、発生ベース、OD ベース、経 路ベース、リンクベースといった様々な単位で表現さ れる。便益計測おいても同様に、発生ベース、OD ベ ース、経路ベース、リンクベースと様々な単位で計測 できる。既往研究 う)では、確定的利用者均衡配分、確 率的利用者均衡配分については、需要固定型・需要変 動型ともに、OD ベース、経路ベース、リンクベース、 それぞれの単位において計測された便益は理論的に 致することが証明されている。しかし、先に示した通 り、消費者余剩アプローチにおける需要曲線は、 without ケースと with ケースとの間を直線近似し、消 費者余劋の変化を台形近似することが通常である。経 路ベースやリンクベースでも消費者余剩の変化を計測 することは可能であるが、新設される道路の禁止価格 を推計する必要がある。経路ベースやリンクベースで、 この禁止価格を推計するためには、数多くのシミュレ ーションを実施する必要が生じるとともに、そのシミ ユレーション如何によっては、台形近似した便益の誤 差が大きくなる場合もある。一方、確定的利用者均衡 配分による OD ベースでの便益計測方法は、OD 間の 各経路間の一般化費用は等しく、また・意に決まるこ とから、without ケースの新設道路の禁止価格は他の 経路の一般化費用から設定されるため、禁止価格を推 計する必要がない。実務で適用するうえで重要となる 作業効率の面からみても OD ベースを単位とする便益 計測が望ましいと言える。

2 ）競合路線の完全代替を仮定しない交通量配分力法 への対応

2.（2）で示した消費者余楼アプローチによる便 益計測の $\triangle \mathrm{GCS} \neq 0$ となる交通需要予測方法は、競合 路線の完全代替を仮定しない配分交通量の予測方法で ある。この要求を満たすための配分モデルとしては、 確率的利用者均衡配分を適用することが望ましいが、 先に述べた課題を抱えているため、現段階において、 実務に適用可能な配分手法は、確定的利用者均衡配分 である。但し、確定的利用者均衡配分は、各経路に配 分される交通量は、Wardrop の第 1 原則である「等時 間原則」を仮定し、経路選択肢間に完全代替性が成立 
することが前提となっている。そのため、競合する 般道路の経路選択肢間はもとより、高速道路（有料道 路）についても有料道路料金を時間に換算したうえで、 旅行時間に加算して、経路選択肢間の完全代替性を仮 定している。有料道路の場合は、一般道路と異なり、

ドライバーは、旅行時間と料金以外の要因によっても 経路選択を行っているため、道路料金を時間に換算す る確定的利用者均衡配分では、高速道路と一般道路の 分担関係を必ずしも適切に推計できない場合がある。 より正確な交通需要予測と便益計測を行うためには、 この問題に対応していく必要がある。この対応力法と しては、ドライバーの経路選択行動をより適切に考慮 できる高速転換率を内生化した利用者均衡配分モデル が考えられる。

本論文では、消費者余剩アプローチによる便益をよ り正確に計測するため、現段階でも実務に適用可能な 「高速転換率内生化利用者均衡配分モデル」を提案す る。なお、ここでの「高速転換率」とは、「高速道路 を使う/使わないりの選択率のことを指す。

高速転換率内生化利用者均衡配分モデルとは、図一 5 に示すように、各 OD 間において・般に複数の経路 が存在するが、それらの経路を、高速道路利用経路 （高速道路を含む経路）と一般道路のみからなる経路 （高速道路を含まない経路）の 2 種類に分けて、確定 的利用者均衡配分を適用するものである（高速道路利 用経路でも、出発地〜高速道入口や高速道出口〜目的 地ではもちろん一般道路を利用すると考える）。具体 的には、高速道路を含む経路群と一般道路のみからな る経路群を、別の交通手段であると見なし、それらの 交通手段間の選択確率は、・種の交通手段分担モデル (ロジットモデル等) で表わされるものと考える。

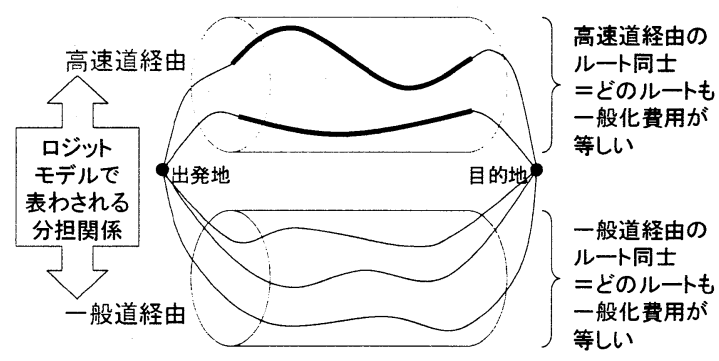

図-5 高速転換率内生化利用者均衡配分の考え方

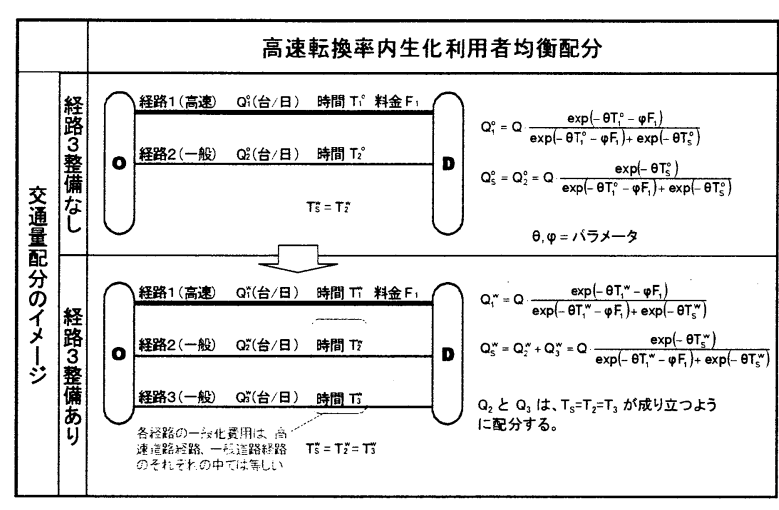

図-6 高速転換率内生化利用者均衡配分のイメージ

高速道路を含む経路群に属する経路同士については、 Wardrop 均衡が成り立つものと仮定し、一般道路のみ からなる経路群に属する経路同士についても同様に、

Wardrop 均衡が成り立つものと仮定する。したがって、 高速転換率内生化モデルは、「高速道路を使う／使わ ない」の交通手段分担モデルと、高速道路および一般 道路それぞれについての経路配分を表わす配分モデル とを統合した「分担一配分統合モデル」の一種と言え る。

このような高速道路利用経路と一般道利用経路間に おりる完全代替を仮定しない配分モデル（高速転換率 内生化利用者均衡配分）が、実務に適用可能となる条 件として、モデル構築に必要なデータの存在している ことが重要となる。具体的には、道路交通センサスを はじめとする OD データによって、全車を対象とした $\mathrm{OD}$ ペア毎に一般道路と高速道路の分担率が把握可能 である。但し、現在の道路交通センサスでは、高速道 路及び 一般道路の利用経路が把握可能できないため、 それぞれについては、完全代替を仮定しない配分モデ ルが適用できないのが実情である。また、高速転換率 内生化利用者均衡配分では、旅行時間と道路料金以外 の経路選択要因も考慮することが可能であり、また、 高速転換率式のパラメータを行動データ等によって適 切に推定することによって、高速道路の利用特性をよ り細かく表現することが可能となり、現沉再現性の向 上や適切な施策感度が得ることができる。

高速転換率内生化利用者均衡配分は、ランダム効用 理論に基づいて選択（高速道路を使う／使わないの選 択）を行うと考えているため、各個人は効用最大の選 択肢（つまり旅行費用最小のモード）を選択すること 
になる。各個人が経路選択によって得られると認識し ている効用は $\max _{m} U_{r s}^{m}$ (但し、 $U_{r s}^{m}$ は $\mathrm{OD}$ ペア $r s$ 間の モード $m$ の効用）である。 $U_{r s}^{m}$ はランダムに変動す る誤差項を含んだ確率変数であるから、 $\max _{m} U_{r s}^{m}$ も また確率変数となる。ここで、 $\max _{m} U_{r s}^{m}$ の平均值を 期待最大効用と呼び、「各個人が認識している効用」 の平均值であると解釈できる。期待最大効用を $-\theta$ で 除して OD 間コストの次元に変換したものが期待最小 コストであり、これは以下に示す式(10)によって計算 される。利用者便益を算出する際には、OD ベースに 基づいて、この期待最小コストを用いればよい。

$S_{r s}=-\frac{1}{\theta} \cdot \ln \left\{\exp \left(-\theta \cdot c_{r s}^{\mathrm{s}}\right)+\exp \left(-\theta \cdot c_{r s}^{\mathrm{H}}-\psi\right)\right\}$ ここに、

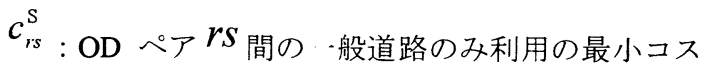
ト（料金を時間換算した項を含む・般化コスト） $c_{r s}^{\mathrm{H}}: \mathrm{OD}$ ペア $r s$ 間の高速道路利用の最小コスト （料金を時間換算した項を含む一般化コスト）

$\theta, \psi$ : 高速転換率式のパラメータ

この高速転換率内生化利用者均衡配分については、 実務で適用された事例(6),7),8，9) もあり、今後、確定的 利用者均衡配分と併せて蓄積を重ねていくことで、十 分に実務での適用に可能な方法であり、消費者余剩ア プローチによるより正確な便益計測に応える実務での 交通需要予測力法である。

\section{5. おわりに}

本論文では、実務における消費者余剩アプローチの 適用を目指した便益計測力法を提案した。具体的には、 経済理論に基づいた便益を正確に計測するための交通 需要予測力法を整理し、その交通需要予測方法が、現 在の実務で、どのように適用できるかを検討した。こ の検討を踏まえ、消費者余剩アプローチによる便益計 測力法の要求に実務上応えることができる交通需要予 測力法として、Wardropの第 1 原則に基づく確定的利
用者均衡配分を発展させた高速転換率内生化利用者均 衡配分を提案した。この高速転換率内生化利用者均衡 配分の適用により、一般道路の競合路線間、高速道路 の競合路線間それぞれについては、完全代替を仮定す るが、一般道路と高速道路間については、完全代替を 仮定しない便益計測が可能となり、消費者余剩アプロ 一チによる便益計測が要求するより正確な交通需要予 測方法に実務面から最大限対応できる。実務で高速転 換率内生化利用者均衡配分を実際に適用するには、高 速道路利用と -般道路利用の選択特性を表すためのデ ータ收集・整備とそれに基づくパラメータ推定が必要 となる。現段階では、全車種を対象としたODペア毎 の高速道路利用と一般道路利用の選択特性を把握でき るのは道路交通センサスのODデータだけであるが、 道路交通センサスのODデータだけでは、ICへのアク セスや高速道路の詳細な経路情報など、詳細かつ正確 な行動データを把握できない面もある。今後は、道路 交通センサスだけでなく、近年急激な普及が進んでい るETCデータやプローブデータの活用等によって、詳 細な高速道路の利用経路に関するデータの蓄積と整備 を行っていく必要がある。また、OD間における高速 道路利用の選択特性についても、旅行時間や料金だけ でなく、ICアクセスへの影響やOD間の利用距離に応 じた高速道路の利用特性等、高速道路利用と一般道路 利用の選択特性を、より適切に表現できるモデル構築 に向けた検討を行っていく必要がある。

実務で道路事業の費用便益分析を実施していくうえ では、経済理論と整合の図られた交通需要予測方法と 実務での適用可能性を理解し、実務面から最大限対応 できる交通需要予測方法に取り組んでいくことが必要 である。今後は、本論文で提案した方法について、 様々な地域や道路ネットワークを対象に、実践的な適 用を蓄積していくことが実務での交通需要予測と便益 計測のうえで重要となろう。

\section{参考文献}

1）桐越 信・安部勝也・毛利雄一：「道路整備における 便益計測方法と交通需要予測方法の関係一消費者余 剩アプローチ」の適用可能性一」高速道路上自動 車, Vol. 48, N0. 7, 2005.

2 ）金本良嗣：消費者余剩アプローチによる政策評価, RIETI Discussion Paper Series 04-J-042, 独立行政 
法人経済産業研究所, 2004 .

3）土木学会：道路交通需要予測の理論と適用

編利用者均衡配分の適用に向けて, 2003.

4) 例えば、土木学会：交通ネットワークの均衡分析 一最新理論と解法一, pp. 170-171， 1998.

5 ）円山环也：交通需要のレベル別便益指標の一致性, Discussion Paper, No. 97, Department of Urban Engineering, University of Tokyo, 2005.

6 ）松井寬, 藤田素弘：大都市圈道路網を対象とした拡張 型利用者均衡配分モデルの開発とその実用化，土木計 画学研究・講演集 No. 22 (2), pp. 1-14, 1999.
7 ）松井寛, 藤田素弘：高速道路を含む都市圈道路網にお ける利用者均衡配分モデルの実用化に関する研究, 土 木学会論文集 No. 653/IV-48, pp. 85-94，2000.

8 ）中村毅一郎, 森田綽之, 井上紳一, 中野敦, 遠藤弘太 郎：首都高速道路における転換率内生化利用者均衡配 分モデルの適用, 土木計画学研究・講演集 No. 29 (CDROM）, 2004.

9 ) 渡邊健司, 中村毅一郎, 森田綽之, 井上紳一：首都高 速道路における利用者均衡配分モデルの適用検討, 第 24 回交通工学研究発表会論文報告集, pp. 153-156, 2004

\section{実務における消費者余剩アプローチの適用を目指した便益計測方法*}

$$
\text { 毛利雄一**・桐越 信***・安部勝也**** }
$$

実務で道路事業の費用便益分析を実施していくうえでは、経済理論と整合の図られた交通需要予測方法を理解 し、本来どのような方法で交通需要予測を行って便益を計測する必要があるか、また実務で適用可能な交通需要 予測方法を理解し、どのような前提条件で便益を計測するのかを整理しておく必要がある。

そこで本論文では、経済理論から正確に便益を計測するための交通需要予測方法と現段階での実務への適用可 能な交通需要予測方法を整理したうえで、経済理論からより正確に便益を計測するための交通需要予測方法とし て、Wardropの第 1 原則に基づく確定的利用者均衡配分を発展させた高速転換率内生化利用者均衡配分を提案し た。

\section{Benefit Measurement Method Aimed at Application of Consumer Surplus Approach*} By Yuichi MOHRI** - Shin KIRIKOSHI*** - Katsuya ABE****

In this paper, the travel demand forecasting method for measuring benefit of the road project more accurately from consumer surplus approach based on an economic theory and the travel demand forecasting method (traffic assignment method) applicable in the present business were arranged. Based on these examination results, the user equilibrium assignment with expressway diversion function was proposed, as the travel demand forecasting method for measuring benefit more accurately from an economic theory. The user equilibrium assignment with expressway diversion function is the model which is developed from the user equilibrium assignment based on the 1st principle of Wardrop. 